\title{
A NEWLy DisCovered FRAGMENT \\ OF THE EARLY IRISH WISDOM-TEXT \\ TECOSCA CORMAIC IN TCD MS 1298 (H. 2. 7)
}

\author{
MAXIM FOMIN
}

\section{Synopsis}

In what follows, I shall attempt to present some preliminary observations concerning a newly discovered fragment of the early Irish wisdom-text Tecosca Cormaic 'Instructions of Cormac' that starts five lines from the bottom of a folio $420^{\mathrm{a}}$, then goes on the folios $420^{\mathrm{b}}-421^{\mathrm{a}-\mathrm{b}}$, finishing off at a folio $422^{\mathrm{a}}$ in the middle with the words ar is triasna techtaib sin do miditer rig 7 flaith ol cormac fri cairbre "“for it is by those qualities kings and lords are judged", said Cormac to Carbre’ (Meyer 1909: 15). ${ }^{1}$

\section{Introduction}

Over a century ago the wisdom-text 'Instructions of Cormac' (Tecosca Cormaic) was edited and translated by Kuno Meyer (1909). Meyer provided a normalised Old Irish version of the text which he mainly based on the readings of the following manuscripts: Dublin, RIA MS 23 N 10 (catalogue number 967, hereinafter $\mathrm{N}^{1}$ ) and RIA MS 23 D 2 (catalogue number 132, hereinafter $\mathrm{D}$ ). He admitted that while $\mathrm{N}^{1}$ was "a careful and trustworthy copy on the whole", D contained "both the most complete and by far the best copy of the Tecosca" (Meyer 1909: ix). ${ }^{2}$

While trying to conclude my work on the diplomatic edition of Audacht Morainn (see Fomin, fc.), I allowed myself to continue reading the Old Irish text contained immediately after its finishing lines in TCD MS H. 2. 7 (catalogue number 1298), and, to my surprise, I instantly recognised the opening lines of the

\footnotetext{
${ }^{1}$ I would like to acknowledge useful advice and extensive comments received from Dr John Carey at the early stage of my research on the H. 2. 7 text. I am also very grateful to Prof Liam Mac Mathúna for his suggestions on the matters of style. I am, however, solely responsible for any remaining errors.

${ }^{2}$ Having said that, Meyer emphasised that he did not have a high opinion of the version of the text contained in the Book of Leinster (see Meyer 1909: viii). However, on many occasions he employed readings of LL in his edition without mentioning their origin and preferred them to perfectly good instances of Old Irish contained in $\mathrm{N}^{1}$.
} 
Tecosca Cormaic (hereinafter TC). These were undoubtedly written down by the same hand as the text of the $\mathrm{A}^{1}$ version of $A M$ that I had just read. Starting immediately after the f./i./n./i./t formula of $\mathrm{A}^{1}$, TC's opening two columns fill up lines 33-37 of the folio $420^{\mathrm{a}}$ - then the text continues on folio $421^{\mathrm{a}-\mathrm{b}}$ in four columns and finishes off in the middle of $422^{\mathrm{a}}$ with the words ar is triasna techtaib sin do-miditer rig 7 flaith ol cormac fri cairbre (cf. Meyer 1909: 14).

\subsection{TCD MS H. 2. 7 (catalogue number 1298)}

The Trinity College Dublin manuscript H. 2. 7 is composed of diverse and varied matter. Its opening 69 folios contain pedigrees of the O’Kellys (Uí Ceallaigh) of Uí Mhaine (Abbott 1900: 78) who were responsible for the compilation of the Book of Uí Mhaine back in the late fourteenth century. The Book of Uí Mhaine (written down by Muircheartach Ua Ceallaigh, bishop of Clonfert between 13781394 and Archbishop of Tuam between 1394-1407) originally contained 368 leaves, but today it is reduced to 161 leaves, four of which are contained in the British Library and the rest in the Royal Irish Academy (O’Neill 1984: 36). The hypothesis that the above mentioned 69 folios belonged to the Book of Uí Mhaine was first expressed by John O'Donovan and later repeated by O'Reilly (Abbott 1900: 79). However, our fragment, contained in "what was formerly a distinct volume" (ib., p. 80) and situated closer to the end of the collection, does not belong to the Uí Mhaine compilation: it is preceded by In Cath Catharda 'The Civil War' (fos. 376-417), a free adaptation of Lucan's Pharsalia, and is followed by the part of Giraldus Cambrensis's Expugnatio Hibernica which treats of the Geraldines (Abbott 1900: 80). ${ }^{3}$ Abbott continues:

p. 418. Auraiccept Moraind, or the Instruction, of Morann to king Feradhach Fionnfachtnach (about A.D. 15-36). A sequel to “Orgain Cairpre Cinn Chait," which is in No. 1337, 761.

It is clear that Abbott did not recognise that the folios in front of him contained two different compositions, and, as a consequence, the part of the manuscript, containing first six paragraphs of Tecosca Cormaic (in Meyer's enumeration) went unnoticed for Meyer and was not employed for his edition of 1909.

\footnotetext{
${ }^{3}$ Having looked at the original manuscript, contained in the manuscript collection of the Trinity College Dublin library, I have instantly recognised that the hand in which the Expugnatio Hibernica is written was strikingly different from that which transcribed both the Audacht Moraind and Tecosca Cormaic.
} 


\subsection{Palaeographic features}

Both Tecosca Cormaic and Audacht Moraind (hereinafter AM) were transcribed by the same hand that (characteristic of Irish scribes noted for their lack of consistency) used both forms of the Irish script, the majuscule (or the Irish halfuncial) - round and solid - and the miniscule - of sharper and more compressed appearance - that can be distinguished by looking at the samples of the capital letter A throughout both texts.

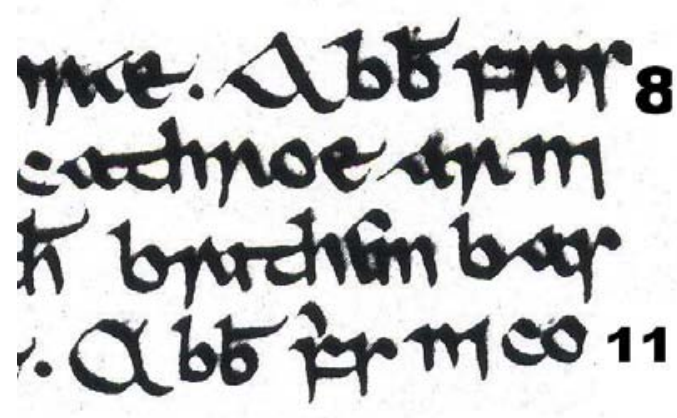

Fig. 1. Fol. $419^{\mathrm{a}} 8-11$

In fig. 1, the capital $\mathrm{A}$ of the phrase Abbair fris 'Tell him' opening of $A M$ 's $\S 31$, fol. $419^{\mathrm{a}}$, (Kelly 1976: 64.99) is written somewhat like ac joined together on line 11 (majuscule type), whereas on line 8 just above, it is made with a straight back in a triangular form (miniscule type).

Similarly, TC's capital A in fol. $421^{\mathrm{b}} 11$, Aithi(n) shlána 'full compensations' (Meyer 1909: 8.27) is written in miniscule whereas capital A right beside it - on fol. $421^{\mathrm{C}} 11$, in the phrase Athair sailli snechta 'snow is the father of fat' (Meyer 1909: 86.4), is written in majuscule (fig. 2).

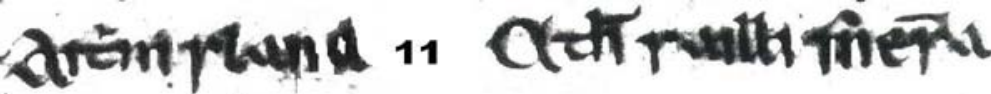

Fig. 2. Fol. $421^{\mathrm{b}} 11,421^{\mathrm{c}} 11$

The fact that both $A M$ and $T C$ 's fragment were written by the same hand can be proved by looking at abbreviations employed by the scribe. These seem quite identical: cp. - us and -ch in $419^{\mathrm{a}} 25$ (beus cach, $A M$, Kelly 1976: 65.118) and in $421^{\mathrm{b}} 26$ (eolus cach, TC,

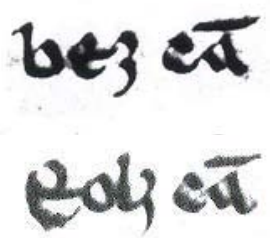

Fig. 3. Fols. $419^{\mathrm{a}} 25 ; 421^{\mathrm{b}} 26$
Meyer 1909: 10.41) (see fig. 3), as well as fri in $419^{\text {b }} 9$ (abair fris, $A M$, Kelly 1976: 66.140) and in $421^{\mathrm{b}} 8$ (fri naimtiu, TC, Meyer 1909: 8.24) (see fig. 4).

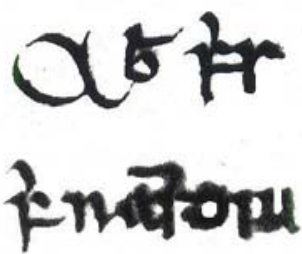

Fig. 4. Fols. $419^{\mathrm{b}} 9 ; 421^{\mathrm{b}} 8$ 


\section{H. 2. 7's fragment of $T C$ in comparison with Meyer's recensions}

The fragment contained in H. 2. 7 was not taken into account by Meyer, but nevertheless contains some early spellings and presents quite an intriguing version of the text. In the treatment that follows, I have not attempted to take into account all the existing copies of the text. ${ }^{4}$ Of the existing manuscripts of the $\mathrm{N}$ recension, RIA 23. N. 10 (catalogue number 967, hereinafter $\mathrm{N}^{1}$ ) and RIA MS 23. N. 27 (catalogue number 966, hereinafter $\mathrm{N}^{2}$ ) were used along with $\mathrm{L}$ recension TCD MS H. 2. 18 (catalogue number 1339, hereinafter LL), TCD MS H. 2.17 (catalogue number 1319, hereinafter Lec) and RIA MS 23 P 12 (catalogue number 535, hereinafter $\mathrm{BB}$ ). For various reasons, $\mathrm{H}$ recension of $T C$ was ignored.

\subsection{Correspondences between the manuscripts of the $N$ recension and $H .2 .7$}

Our fragment cannot be definitely assigned to any of Meyer's recensions; from a cursory look, however, it seems probable that it was based on a version which was also used as one of the sources for the compilation of $\mathrm{N}^{1}$.

\subsubsection{Additional material in $N^{1}, N^{2}$ and H. 2. 7}

Meyer adds in a footnote to $\S 1.7$ frithfholad fír 'giving truth for truth' (Meyer 1909: 2-3, note 8) that the $\mathrm{N}^{1}$ (reading fritholaid fír) also contains an additional line frithfola fri araile. H. 2. 7 reads the line as frithailim firinni, and yet, adds frithfola fharaili which is a corrupt form of $\mathrm{N}^{1}$, s frithfola fri araile 'reciprocal services to each other'. This additional line is not attested in any of the other manuscripts. For §3, other instances of material contained only in the $\mathrm{N}$ recension and in H. 2. 7 include $\$ 3.19$ comúaim coimgne 'weaving together synchronisms'

\footnotetext{
${ }^{4}$ In his introduction, Meyer surveys the three main recensions (N, L and $\mathrm{H}$ ) and the individual manuscripts in each containing the text of TC.

The so-called $\mathrm{N}$ recension comprises versions of the text found in such manuscripts as Dublin RIA MS 23 N 10 (catalogue number 967, fos. 1.1-5.21), Dublin RIA MS 23 N 27 (catalogue number 966, fos. 7b-32b), Dublin TCD MS H. 5. 19 (catalogue number 1391, pp. 97.1-128.11), and RIA MS 23 D 2 (catalogue number 132, pp. 5.1-25.2).

The L recension comprises versions of the text found in the Book of Leinster (Dublin TCD MS H. 2. 18, catalogue number 1339, fos. 343-5), Great Book of Lecan (TCD MS H. 2. 17, catalogue number 1319, fos. $145^{\mathrm{va}} 1-146^{\mathrm{vd}} 14$; also RIA MS 23 P 2, catalogue number 535, fos. $420^{\mathrm{a}}-422^{\mathrm{a}}$ ), Book of Ballymote (RIA MS 23 P 12, catalogue number RIA 535, fos. $39^{\text {va }} 44-40^{\text {vb }} 42$ ); a copy of this version is to be found in the Book of Uí Mhaine (RIA MS D II 1, catalogue number 1225, fos. $130^{\text {ra }} 14-133^{\text {rb }}$ 9) which Meyer (1909: x) did not use. Finally, National Library of Scotland MS Adv 72.1.1 (fos. $9^{\mathrm{a}} 1-9^{\mathrm{b}} 2$ ) and its copies, e.g. NLS MS G 42 (fos. 214-228.16), TCD MS H. 4. 8 (catalogue number 1349, full MS is devoted to TC) and TCD H. 2. 4 (catalogue number 1295, fos. 131-133d 36), also belong here. In Meyer's view, a late and extremely corrupt $\mathrm{H}$ recension is contained in TCD MS H. 1. 15 (catalogue number 1289, pp. 149-174) and TCD MS H. 1. 9 (catalogue number 1283) which was evidently disregarded by him.
} 
(Meyer 1909: 8-9), the last words of $\S 3.51$ (ar cach n-olc 'against every evil', Meyer 1909: 10-11) and §3.52-3 in their entirety that I reconstruct as Ní ba rethide oc less túaithe | Ní ba gerthide i n-ailt midchúarto 'Let him not be hasty as far as the profit of the kingdom is concerned | Let him not be fatty in the house of mead-court'.

§6.11-17 are extremely revealing in this connection. They are arranged in paired alliterating sequences preceded by rop 'let him be'; and in some, the first member of a pair is omitted in the manuscripts of the $\mathrm{L}$ recension. Thus, the first parts of $\S 6.11,12,13,17$ of our edition corresponding to rop fili... gáeth ... sochraid ... áintech 'let him be a poet... wise... decorous... abstinent', of Meyer (1909: 12-15, §6.12, 14, 16, 26), are only preserved in the manuscripts of the $\mathrm{N}$ recension and H. 2. 7 and are absent in those of L. The maxim báthed cach $n$ anslicht 'let him quell every wrong' (Meyer 1909: 14-15, §6.30) is also entirely omitted in the manuscripts of the $\mathrm{L}$ recension as well as in $\mathrm{N}^{2}$. Finally, toward the end, in the lines which I reconstruct as rop cuimrechtaid uilc / rop smachtaid coisc 'let him be a reprover of evil / let him be a ruler of restraint', the L recension seems to have had one line originally which was later expanded into two: rop cuindrigid coisc 'let him be a reprover of restraint' (cf. LL 45888) where both cuindrigid and cuimrechtaid are variant forms of the verb con-rig 'constrains' of which cuindrigid is an earlier form, however, the word cuimrechtaid is obviously a Middle Irish formation.

Finally, it is extremely important to note that Meyer, following the order established in the $\mathrm{L}$ recension, changed the sequence of sections within his edition in relation to a separate section devoted to the description of the weathers (OIr. sína, Meyer 1909: 36, §17). In the $\mathrm{N}$ recension manuscripts and in $\mathrm{H}$. 2.7 the section on proper weathers is contained between the so-called third (starts with cid as dech do less túathe 'what is best for the good of the tribe?') and the fourth (cadeat ada flatha ${ }_{7}$ cuirmthige 'what are the dues of a chief and of an ale house?') sections of TC in Meyer's edition. Contrary to the evidence of the $\mathrm{N}$ recension manuscripts, Meyer was keen on linking together (probably, for the sake of preserving the flow of the text) the line ní ba gerthide i n-ailt midchúarto, 'let him not be greasy in the mead-court house', contained only in the manuscripts of the $\mathrm{N}$ recension (and, unknown to him, in H.2.7) and absent in the manuscripts of $\mathrm{L}$ recension, and the opening question of the fourth section, cadeat ada flatha ${ }_{7}$ cuirmthige 'what are the dues of a chief and of an ale-house?' (Meyer 1909: 1011), which, in the case of the $\mathrm{N}$ recension (and H. 2. 7 fragment) only crops up after a section on proper weathers. 


\subsubsection{Innovations and lectiones difficiliores of the $L L$ version}

Some examples can be noted throughout the text where LL reflects innovation, providing distinct and peculiar readings, as well as the variants that can be regarded as lectiones difficiliores.

A peculiar example of LL's tendency to innovate is a visible §1.31's torramad lubru 'let him attend to the sick' of Meyer's edition (1909: 4-5) where for the last word LL's scribe has inserted eslánu 'unhealthy' on an erasure.

In case of §2.10 (comúaiged síd 'let him consolidate peace’, Meyer 1909: 6-7), LL as well as the other manuscripts of the L recension employ a different verb, codnaigid 'commands, controls', which crops up only in later sources (DIL S.v.).

Comparing various readings of $\$ 3.22$ cotach cen timdibe 'a covenant without curtailment' (Meyer 1909: 8-9), one can note that in contrast to the reading of the last two words as gan timdib(h)e in the $\mathrm{N}$ recension and cen timdibi in H. 2. 7 version, LL (with Lec) employs a word of uncertain meaning (irchaire; DIL s.v. ?airchaire; $c f$. also BB's icaire), also omitting the preposition cen 'without'.

The later forms of $\mathrm{N}^{2}$ s fostad and H. 2. 7's fostud agree with each other as the first element in $\$ 3.29$, contrary to the reading of LL which Meyer took as primary: astud cundrada cen diupairt 'keeping a bargain without detriment' (Meyer 1909: 8-9, §3.30; cf. asta as lectiones difficiliores of BB and Lec).

Druine mrechtrad 'skill in variegated work' as established by Meyer (1909: $10-11, \S 3.42$ ) is closer to the reading of $\mathrm{N}^{12}$ and H.2.7 (mbrechtraid) than to druine cech br(e)ithe(a)m(h)nais 'skill of every judgement', that can be found in the manuscripts of the $\mathrm{L}$ recension considered here.

Scélugud ngairit 'short story-telling' established by Meyer (1909: 10-11, $\S 4.13$ ) on the basis of the readings of $\mathrm{N}$ recension agrees with $\mathrm{H}$. 2. 7 that reads scelugud against the $\mathrm{L}$ recension whose manuscripts provide an array of corrupt verbal forms (LL Reclugud BB Reaglugad Lec Reclumad) not attested elsewhere.

Also in §4, N's toé fri comad 'silence during recital' (Meyer 1909: 12-13, §4.16) agrees with H. 2. 7’s tuae against L's feidle 'constancy'.

In the last paragraph of H. 2. 7, rop cuimnech maithiusa 'let him be mindful of good' (Meyer 1909: 14-15, §6.34) is the reading that can be established on the basis of the $\mathrm{N}$ and $\mathrm{H}$. 2. 7 recensions whereas $\mathrm{L}$ not only substitutes éstid 'listener' for cuimnech 'mindful', but also inserts cech 'of every' in front of maithiusa. 


\subsubsection{The use of prepositions}

In his note to §1.9 slógad fri deithbiri 'hosting with reason’ (Meyer 1909: 2-3, n. 9), Meyer points out the reading of the preposition in $\mathrm{N}^{1}$ as $l a$ 'with' whereas other recensions prefer fri 'against': $c f$. BB $=$ Lec fri, $\mathrm{N}^{2} f[r] i u$ and LL [f]ri. H. 2. 7 disagrees with the latter, reading le with $\mathrm{N}^{1}$.

A few lines below, at 1.19 of Meyer's edition, torud inna fhlaith 'fertility during his reign', manuscripts agree on reading inna fhlaith (e.g. $\mathrm{N}^{1}$ ina flaith, $\mathrm{N}^{2}$ na fhlaith, LL inna flaith, BB na flaith, Lec na flaitheas) whereas H. 2. 7 prefers fria fhlaith. We should probably follow the latter, taking fri in locative sense characteristic of its use in OIr. in expressions of time (DIL, s.v. fri IX (a)).

On the contrary, in §2.28 (in Meyer's rendering: foltaib fíraib do thúathaib 'with just substances to the tribes', Meyer 1909: 6-7, §2.24), I prefer the reading do t(h)úathaib of the earlier manuscripts (i.e. $\mathrm{N}^{1}, \mathrm{LL}$ and Lec) to those of the later ones (i.e. $\mathrm{N}^{2}$ and $\mathrm{BB}$ ) with H. 2. 7 concurring with the latter: $\mathrm{N}^{2}$ fri tuathaibh $\mathrm{BB}$ fri tuathaib, H. 2. 7 fri tuathaib.

Towards the end of the paragraph, in timmoirged cách fo recht 'let him bring each one under law' (Meyer 1909: 6-7, §2.30), H. 2. 7 however agrees with $\mathrm{N}^{12}$, reading (co) cach fo recht against manuscripts of the L recension: LL cech recht, BB cach for airecht, Lec cach recht.

A different scenario is evident in trócaire co ndagbésaib 'mercifulness with good customs' (Meyer 1909: 8-9, §3.17), in which H. 2. 7 probably preserved an earlier tradition echoed by a reading of $\mathrm{N}^{2}: \mathrm{N}^{1}$ co ndegbesaib, LL co ndagbés, BB con deghbhes, Lec co ndegbesaib vs. $\mathrm{N}^{2}$ fri dheaghbheusoibh, H. 2. 7 fri daghbéiso.

The confusion of $d i$ and $d o$ in proclisis was characteristic of OIr. texts from an early period (DIL, s.v. 1 de, di, D-degóir, 129.39-13.2), and there are plenty of examples of this phenomenon in our text. In géill do inchaib 'hostages for honour' (Meyer 1909: 8-9, §3.34), H. 2.7 reads di against other manuscripts that prefer do: $\mathrm{N}^{2}$ do inochoib, LL do inchaib, BB do incaib, Lec do inchaib, H. 2. 7. di inchaib. A similar scenario is repeated in cech fhir do neoch is leis 'of every man of whatever is his' (Meyer 1909: 6-7, §2.22), when H. 2. 7. reads di nioch against do neoch of other manuscripts. Whereas at the start of the third paragraph (fochmarc di gáethaib 'questioning the wise', Meyer 1909: 8-9, §3.7), H. 2.7 agrees with the majority against $\mathrm{N}^{1}$. The readings are: $\mathrm{N}^{2}$ do ghaethuibh, LL do gaethaib, BB do gaethaib, Lec do gaethaib, H. 2. 7 do gaethaib vs. $\mathrm{N}^{1}$ di gaethuib. All those inconsistencies can be, on the one side, explained by preservation of a more archaic forms in H. 2. 7 or else as examples of pseudoarchaism. 


\subsubsection{Unstressed $-e-$}

As far as $\$ 1.44$ imbed fína sceo meda 'abundance of wine and mead' (Meyer 1909: 4-5) is concerned, not only do the $\mathrm{N}^{12}$ and H. 2.7 manuscripts agree on the matter of listing the drinks as meda sceo fína against fína sceo meda in the manuscripts of $\mathrm{L}$ recension (LL, BB and Lec), but $\mathrm{N}^{1}$ and H. 2.7 also retain the archaic form of spelling of $-e$ - in the unstressed position (against $-a-$ of the standard Old Irish forms attested in the majority of our manuscripts: $\mathrm{N}^{2}$ iomad, LL immad, BB immad, Lec imad) of the first word, reading it as immed in H. 2. 7 and imbet in $\mathrm{N}^{1}$.

\subsubsection{Treatment of OIr. mr-}

In §3.42 druine mrechtrad 'skill in variegated work' (Meyer 1909: 10-11), the last word of the line represents a normalised Old Irish spelling of the intermediate form mbrechtrad preserved in the manuscripts of the $\mathrm{N}$ group and in $\mathrm{H}$. 2. 7 (mbrechtraid) against L's innovation (brithemnais) attested in LL, BB and Lec.

\subsection{Correspondences between H. 2. 7 and Rec. L manuscripts}

Still, some contrary evidence can be recalled in which H. 2. 7's readings come closer to those of the L recension. On a closer look, they mostly occur in the socalled third paragraph of TC (in Meyer's enumeration).

\subsubsection{Earlier verbal formations}

Note that in $\$ 1.11$ trocaire co ndlúthugud rechta 'mercifulness with consolidation of law' (Meyer 1909: 2-3) the manuscripts of the L recension are unanimous in choosing a verbal noun of dlúthaid, attested already in the Würzburg and Milan glosses, reading it as dluthud in LL, dluthadh in BB and Lec. H. 2. 7. also prefers dluthud whereas $\mathrm{N}$ recension prefers a later verbal noun of dlúthaigid $\left(\mathrm{N}^{1}\right.$ con dluthugad, $\mathrm{N}^{2}$ dluthugadh) which is to be found only in Middle Irish texts (DIL s.v.).

\subsubsection{Confusion between imperative and present indicative forms}

Manuscripts greatly diverge in §2.11 clannad dliged 'let him plant law' (Meyer 1909: 6-7). Only Lec is clear in relation to an ipv. form clandad, whereas LL and H. 2.7 treat the form as $3 \mathrm{sg}$. pres. ind. clannaid. $\mathrm{N}^{2}$ reads clanuighed, whereas $\mathrm{N}^{1}$ and $\mathrm{BB}$ treat it as claindaiged. The correspondence between the readings of LL and H. 2. 7, however, does not suppose any influence of the traditions here in view of another agreement between two manuscripts from two different recensions, $\mathrm{N}^{1}$ and $\mathrm{BB}$. 
\$2.13 dóerad bidbadu 'let him enslave criminals' could have proven to be another example of the correlation between H. 2. 7 and $\mathrm{L}$ recension in their treatment of verbal forms, and yet the agreement is not with $\mathrm{L}$ on the whole, but with LL in particular. As in the previous instance, LL and H. 2. 7 agree in their treatment of the verb as $3 \mathrm{sg}$. pres. ind. doeraid. Again, Lec provides an ipv. daerad, and BB agrees with Lec, reading this with a marked lenition over its ending as doeradh. $\mathrm{N}^{2}$ reads dioradh. Its final consonant is also marked by lenition and the reading looks like a hapax legomenon of the form attested in $\mathrm{N}^{1}$ (daoiradh).

\subsubsection{Preservation of $-n-$ after $-l-$}

In §3.9 comalnad cech maithiusa 'fulfilling every good' (Meyer 1909: 8-9), the reading of the first word with a preservation of $n$ after $l$ is observed in $\mathrm{N}^{1}$ (comallnadh) with a mark of lenition over the final consonant, whereas in other

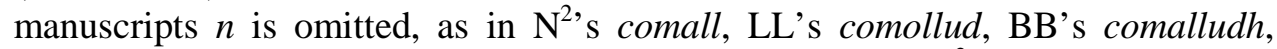
Lec's comallad and, finally, H. 2. 7's comallud. Note that $\mathrm{N}^{2}$ dropped the ending entirely.

\subsubsection{Treatment of the diphthongs}

In §3.10, airecht ríaglach 'an assembly according to rules' (Meyer 1909: 8-9), Meyer clearly prefers treating the second word in this line as an adjective formed on the basis of the noun ríagol 'rule'. The consensus between $\mathrm{N}^{12}$ Lec (riaglach) and $\mathrm{BB}$ (riaghlach) manuscripts (vs. LL and H. 2. 7's riglach) points to ríaglach, a very rare doublet of ríagalta, thus one can read 'an assembly governed by rule'.

\subsubsection{The use of relative}

The readings of $\$ 1.29$ clause rendered as ar choimét cacha túaithe 'to protect every tribe' (Meyer 1909: 4-5) diverge in $\mathrm{N}^{1}$ as opposed to other recensions. $\mathrm{N}^{1}$ 's ara:coimédait preserved the relative form of the preposition ar 'in order that' followed by rel. 3 pl. pres. ind. of coimétaid 'keeps, guards' in contrast to the combination of the preposition ar 'for' and the verbal noun in other manuscripts: $\mathrm{N}^{2}$ fri coimhed, LL ar cometa, BB ar coimed, Lec ar choimet, H. 2. 7 ar a cométa.

\subsection{H. 2. 7: Concise treatment of orthographical and grammatical features}

A few archaic and a number of standard Old Irish spellings which were preserved here better than in other manuscripts show that the text of H. 2.7 is of an earlier date than those contained in other recensions and in many instances can facilitate our reading of the text. On the other hand, there are plenty of examples of Middle 
Irish features and pseudo-archaisms, which point to a later date for its compilation. Therefore, it can be tentatively dated to $c$. AD 1150, although it is clear that the text was copied from an earlier exemplar, from which parts of the $\mathrm{N}$ recension also derive.

\subsubsection{Archaic features}

The older spelling of már 'great' as opposed to mór is found once in §1.18 adrad Dé móir 'worshipping great God' (Meyer 1909: 2). ${ }^{5} \mathrm{H}$. 2. 7’s már agrees with $\mathrm{N}^{2}$ that reads máir in contrast to móir, attested in all manuscripts of L.

\subsubsection{Middle Irish features: nasalised genitive constructions}

Inorganic nasalisation in genitive constructions which is typical of Middle Irish constructions is quite a regular feature in H. 2. 7 and in N. Such instances can be recalled as n-diubairta, $n$-daghdáine, n-almsan in \$3.4 (terchomrac dagdóine, Meyer 1909: 6), §3.31 (fuillem ndiuparto 'interest on detriment', Meyer 1909: 8), and §3.45 (tabairt almsan 'giving alms', Meyer 1909: 10), whereas manuscripts of L agree in regard to readings diubarta, degdáine (with Lec slightly at odds with the rest, inventing meic ndeagdaine) and almsan.

\subsubsection{Distinction of final vowels $-a,-O,-u$}

In contrast to standardised $\$ 2.5$ marbad ulcu 'let him slay evildoers' of the edition, manuscripts of $\mathrm{N}$ recension and $\mathrm{H}$. 2. 7 agree on inserting már between the two words (Meyer 1909: 4-5, also note 21), thus reading marbad márulcu 'let him slay great evil ones' (with complex line-internal alliteration).

In the last example, H. 2. 7 reads ulcu against ulca of $\mathrm{N}^{2}$. In other instances H. 2.7 also regularly provides examples of classical Old Irish spelling of acc. pl. in - u, e.g. §1.31-32 lubru... triunu against $\mathrm{N}^{12}$ lub(h)ra ... triuna (Meyer 1909: 4-5, note 3); §2.14 enngu against $\mathrm{N}^{1}$ s andga and $\mathrm{N}^{2}$ s eannga (Meyer 1909: $6-7$, note 5) etc. It is clear that $-a$ and $-u$ have fallen together in $\mathrm{N}$ and appear frequently as $-a$ and occasionally as $-a i,-a e$, and $-o$. They are treated as separate in H. 2. 7. However, a more detailed analysis of H. 2. 7's readings is required as they should appear in Old Irish; the ending $-u$ is still to be found quite frequently in such Middle Irish sources as LL and LU.

\footnotetext{
${ }^{5}$ On the use of már as an earlier form (rather than mór) and as a dating criterion see Kelly (1976: xxxi), who warns, however, of its unreliability as an absolute criterion in view of the two forms being attested in the ninth-century Milan glosses.
} 


\subsection{Stemma}

Drawing to a conclusion, let us point out that the discrepancies between $\mathrm{N}$ and H. 2. 7 are, however, few and unimportant. One can note plenty of parallels between the manuscripts of the $\mathrm{N}$ recension, on the one hand, and $\mathrm{H}$. 2. 7, on the other. However, there are many cases where recension L manuscripts, and in particular LL, have at least as good a claim to the earlier reading as has N. More analysis is required of the occasions where H. 2. 7 agrees with LL and especially with Lec. Therefore, a following tentative stemma might be proposed:

Lec

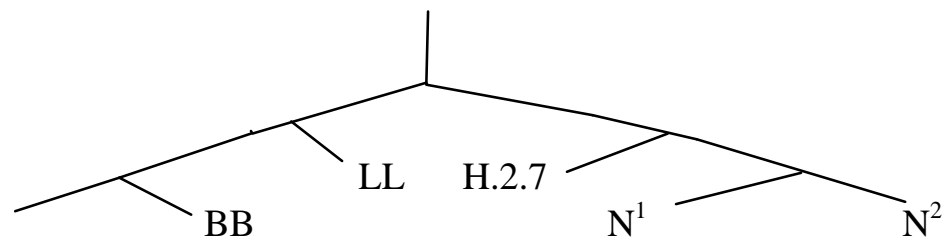

\section{Conclusion}

Observations contained in this contribution are necessarily of a somewhat preliminary character. A lot of work has yet to be done in order to produce a proper edition of Tecosca Cormaic that would replace the one by Meyer which is for many reasons inaccessible and in many instances outdated. The importance of the fragment's discovery discussed here lies in the significance that the first part of TC played in the mindset of the compiler. Having continued the flow of compilation of the manuscript by switching from Audacht Moraind to Tecosca Cormaic, the scribe outlined the equal importance of both - of AM's exquisite elaborations on the fortunes of righteous kingship and of $T C$ 's simple and laconic question-and-answer formulae (on the diversity of their stylistics and syntactic patterns - but not the subject-matter - see Fomin 2009). Such equal standing serves only to prove that both wisdom-texts were equally embedded into the single mental matrix of the compiler and constituted important components of the paradigm of ideal ruling in early Ireland. 


\section{Abbreviations}

AM - Audacht Moraind (Kelly 1976)

TC - Tecosca Cormaic (Meyer 1909)

LL - The Book of Leinster (TCD MS H. 2. 18, catalogue number 1339)

BB - The Book of Ballymote (RIA MS 23 P 12, catalogue number 535)

Lec - The Great Book of Lecan (TCD MS H. 2.17, catalogue number 1319)

\section{References}

Abbott, T. K., 1900, Catalogue of the Manuscripts in the Library of Trinity College, Dublin, Dublin: Hodges \& Figges; London: Longmans.

Fomin, M., 2009, 'Wisdom-texts from Early Christian Ireland: Aspects of Style, Syntax and Semantics', in: M. Bloch-Trojnar, ed., Perspectives on Celtic Languages, Lublin Series in Celtic Linguistics 6, Lublin: Wydawnictwo KUL, 161-186.

Fomin, M., fc., Images of Ideal Kingship in Early Irish Wisdom Literature.

Kelly, K., ed., 1976, Audacht Morainn, Dublin: DIAS.

Meyer, K., ed., 1909, Tecosca Cormaic. The Instructions of King Cormaic Mac Airt, RIA Todd Lecture Series 15, Dublin: RIA.

O’Neill, T., 1984, The Irish Hand, Portálaoise: Dolmen. 